\title{
EVALUATION OF TYPOLOGY OF LANDSCAPE ELEMENTS IN TERMS OF RURAL PLANNING
}

\author{
Esra ÖZHANCI \\ Nevşehir Hacı Bektaş Veli University, Turkey \\ eozhanci@nevsehir.edu.tr \\ https://orcid.org/ 0000-0003-2789-6380
}

\begin{abstract}
Sustainable development is possible with a balance and harmony in social, economic and environmental terms. This harmony constitutes the trivet on which the landscape planning is established. Change and conversion is established on sound grounds with sustainable usage. A landscape is shaped as a result of the perceptions, needs and behaviors of its habitants, visitors and users. Assessing landscape elements located in different character areas with their typology is a method that facilitates perception studies. It will be possible to shape landscapes by placing ideas in a faster manner with typological generalizations on the structural elements of each character. In this study, simulations have been formed over different scenarios for the purpose of assessing rural area elements in a typological manner, and these images have been subjected to participant assessment with the Preference Experiment (PE). As a result, linear, massive and scattered elements were determined as the outstanding typology of Mountain Landscape; curved and segmental elements were determined as the outstanding typology of Water Front Landscape; and linear, point and scattered elements were determined as the outstanding typology of Plain Landscape.
\end{abstract}

Keywords: Visual Landscape, Landscape Typology, Rural Area.

\section{PEYZAJ ELEMANLARININ KIRSAL PLANLAMA AÇISINDAN TİPOLOJIKK DEĞERLENDİRMESİ}

\section{ÖZ}

Sürdürülebilir gelişme sosyal, ekonomik ve çevresel açıdan denge ve uyum ile mümkündür. Bu uyum ise; peyzaj planlamanın üzerine inşa edildiği üçlü sacayağıdır. Değişim ve dönüşüm, sürdürülebilir kullanımlarla sağlıklı bir zemine oturur. Bir peyzaj, sakini ve ziyaretçisi ile kullanıcının algı, ihtiyaç ve davranışlarının sonucu olarak şekillenir.Farklı karakterdeki alanlarda yer alan peyzaj unsurlarını tipolojisi ile değerlendirmek, algı çalışmaları açısından kolaylık sağlayacak bir yöntemdir. Her karakterin yapısal unsurları üzerine, tipolojik genellemelerle daha hızlı fikir ortaya koyarak, peyzajları şekillendirmek mümkün hale gelecektir. Bu çalışmada; kırsal alan unsurlarının tipolojik olarak değerlendirilmesi amacıyla farklı senaryolar üzerinden simülasyonlar oluşturulmuş, bu görüntüler Tercih Deneyi (TD) ile katılımcı değerlendirmesine tabi tutulmuştur. Sonuç olarak; doğrusal, kitlesel ve dağınık unsurlar Dağ peyzajının öne çıkan unsurları olmuş, Su kıyısı peyzajında; kavisli, parçasal unsurlar öne çıkmış, Ova peyzajında ise; doğrusal, noktasal ve dağınık unsurlar peyzajın öne çıkan tipolojiler olmuştur.

Anahtar kelimeler: Görsel Peyzaj, Peyzaj Tipolojisi, Kırsal Alan.

\section{INTRODUCTION}

The population of the world is increasing in a fast pace with each passing day. United Nations foresees that the population of the world will reach 9,6 billion by the year 2050 (Anonymous, 2013a). In order to prevent future food crises, agricultural productivity must be increased with a sustainable, flexible

Submit Date: 16.07.2019, Acceptance Date: 29.10.2019, DOI NO: 10.7456/11001100/002

Research Article - This article was checked by Turnitin

Copyright $\mathbb{C}$ The Turkish Online Journal of Design, Art and Communication 
and convenient manner in order to ensure rural development and decrease poverty (Anonymous, 2014). Such an increase in the world population also brings increasing demands with it. In this context, the importance of agricultural areas and agricultural products is increasing day by day. In addition, agricultural landscapes receive an increasing value by the society because of their characteristics like being the landscape beauty and the habitat for bio-diversity, and due to their potentials in providing versatile benefits and values (Soy-Massoni et al., 2016). It is necessary to analyze this rising value correctly and evaluate all aspects of its components.

The conversion of natural ecosystems into agricultural areas or into urban areas or the use of ecosystems in various densities has converted more than $80 \%$ of the global surface area. Many studies have focused on how field conversions created agricultural areas and human-active landscapes, and the issues of characterizing the spatial change in agricultural landscapes have attracted less attention (Van der Zanden et al., 2016). The enlargement and intensifying strategies applied to increase agricultural yield and production must cover the demands, and increase the agricultural yield and total production. However, this situation decreases the quality of water, consumes the food in the soil, decreases the regeneration ability of local species and damages the ecosystem (Sato et al., 2013). One of the aims of European Union Bio-diversity Strategy 2020 is establishing green infrastructure until 2020 and sustaining, developing it with ecosystems, and repairing at least $15 \%$ of the disrupted ecosystems (Anonymous, 2011). Sustainability of agricultural ecosystems and services is also an important part of this issue. The value of agricultural landscape refers to a whole with different components.

With rare cultural heritage and values, the land cover, land management and the structure of the land are central properties that make landscape different. Cultural landscape is a term, which was accepted as of 1990 s in international community in protection status. All the elements like its being more complicated in structural terms, traditional and low-intensity landscape applications and historical elements contribute to the rare value of these landscapes (Van der Zanden et al., 2016). The European Landscape Agreement defines landscape as "the area whose character is formed as a result of the action and the interaction between the natural and/or human factors, and is perceived by humans" (Anonymous, 2000). The emphasis of the perception reveals again that the landscape perception area is a concept located in the very center of landscape assessment. As a matter of fact, many studies have been conducted in recent years on perception, and the results of this interaction have been based on a numerical basis. In the light of this information, the importance of the rural areas in terms of biodiversity and ecosystem cannot be denied as well as for sustaining human life. Agricultural areas and activities, forests and natural vegetation, meadows and grasslands and animal husbandry are the basic elements of rural areas in our country. In this context, it is compulsory that these functions that are both inseparable and are contrary to each other are established on a sustainable balance.

Rural landscapes express aesthetical and recreational values for users. They are perceived and assessed in this manner. Aside from this, the preferences may vary according to family, environment, education, culture and similar personal characteristics (Brown and Daniel, 1987; Kaplan and Talbot, 1988; Hull and Revell 1989; Van Zanten et al., 2016). There are two main landscape aesthetics theories paradigms that are based on landscape assessment methods; "objective" paradigm (visual quality according to landscape features), "subjective" paradigm (the landscape quality "in the eye of the audience"). The analysis of the relations between the visual quality and structural features of the landscape is an active study field in which environmental perception research is what counts (Fuante de Val et al., 2006). Many methods(Paquette and Dammon, 2003; Arriaza et al., 2004; Turk, 2006; Rogge et al., 2007; Gruehn and Roth, 2008; Lokocz et al., 2011; Cloquell-Ballester et al., 2012) have been applied for visual landscape analysis and assessment until our present day .

Landscape perception and landscape preferences should be associated with both insiders and outsiders, landscape policies should be determined from the perspective of the various groups. In recent years,

Submit Date: 16.07.2019, Acceptance Date: 29.10.2019, DOI NO: 10.7456/11001100/002

Research Article - This article was checked by Turnitin

Copyright (C) The Turkish Online Journal of Design, Art and Communication 
the landscape parameters (forestation, heterogeneity, area usage density, etc.) of various areas have been assessed in terms of preference with Preference Studies based on perception and with expert approaches in the world (Arnberger \& Eder, 2011; Vecchiato \& Tempesta, 2013; Van Zanten et al., 2016). However, it is not correct to perform one single assessment for wide landscape areas; the assessments must be performed over regional landscape characters. In this context, it has been concluded that the urban area works at country and region scale are inadequate, and authentic landscape elements cannot be assessed in terms of typological distribution (point, linear, massive, scattered, curved, and segmental). The purpose in this study is to seek the answer to the question of which different landscape scenarios (represented with point, linear, massive, scattered, curved, and segmental elements) will influence the preference with the Preference Experiment (PE) in the sample case of Coruh Valley in terms of landscape character in similar valley types in the region and in the country.

\section{MATERIAL AND METHOD}

The material of the study consists of visual simulations that include different element variations. These simulations have been formed as based on the geographical characteristics of the Upper Coruh part of Coruh Valley, which constitute the ground for many hydroelectric power plants in recent years with important natural and cultural sources. Upper Coruh Valley is the part where the river runs through the cities of Erzurum-Bayburt(Turkey) (Figure 1). The valley is surrounded by Aras in the east, Eastern Black Sea and Yesilirmak in the west, and Firat-Dicle basins on the south. The general area of the basin is 2.025.608 hectares (Anonymous, 2013b). It is presumed that the area was formerly covered with forests. In our present day, steppe formation is widespread in the area. The steppe in the area consists of bright flowered short plants with a very short lifespan. The forests in the area are located as small coppice forests especially in the mountainous areas where the Coruh Rivers starts to run (Özey, 1988). The forest areas consist of the unity of one or more of Pinus sylvestris L., Quercus sp., Populus $s p$. ., Juniperus sp. In addition, there are also Populus sp. and Salix sp. species along the Coruh River.

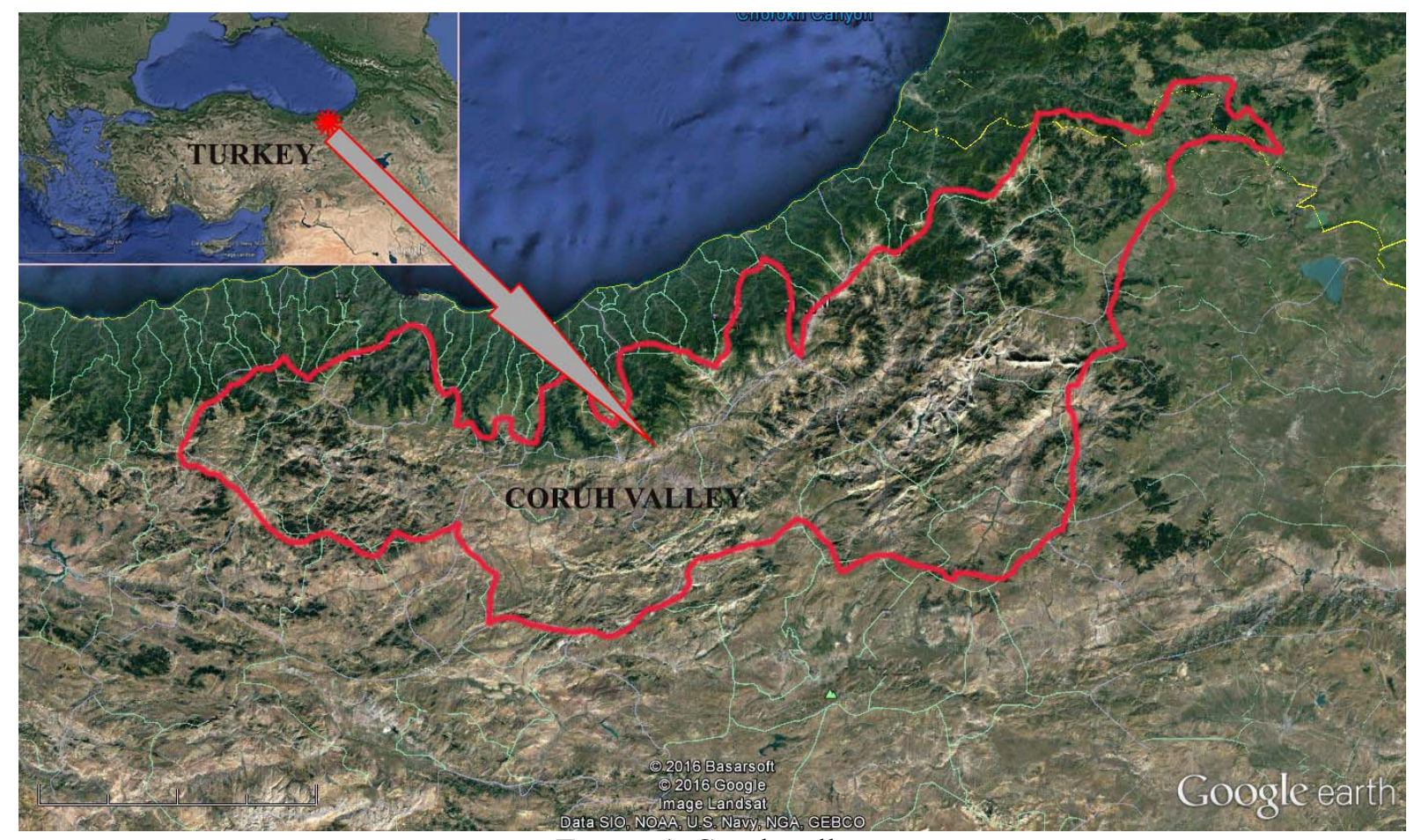

Figure 1. Coruh valley

Research Article - This article was checked by Turnitin

Copyright (C) The Turkish Online Journal of Design, Art and Communication 


\section{METHOD}

The Preference Experiment (PE) was conducted with the images presented to the participants (Westerberg et al., 2010; Arnberger \& Eder, 2011; Lokocz et al., 2011; Cloquell-Ballester et al., 2012; Vecchiato \& Tempesta, 2013). Nine scenarios were characterized over 3 different rural landscape types for this purpose (Figure 2). The animal existence was also included in the study as one of these representation elements. The scale that was formed for this purpose is as follows;

For Mountainous Area Landscape; animal existence (no:1; yes:2), linear element (no:1; fence:2, treefence:3), massive element (vegetation, no:1, vegetation, yes:2), scattered element (vegetation, no:1; vegetation, yes:2).

For Plain Landscape; linear element (vegetation, no:1; vegetation, partly:2; vegetation wholly:3), curved element (road, no:1; road, yes:2), point element (no:1, one element:2; two elements:3), scattered element (bundle in agricultural area, no:1; bundle in agricultural area, yes:2).

For Water Front Landscape; curved element (road, no:1; road, yes:2), segmental element (agricultural area, no:1; agricultural area, yes:2), animal existence (no:1; yes:2), point element (no:1; yes:2).

The Experiment Group was formed by university students who were studying at various scientific departments. The Experiment Group, which had 95 participants, consisted of Nevşehir Hacı Bektaş Veli University, Engineering-Architecture Faculty, Metallurgy and Material Engineering, $2^{\text {nd }}$ Grade students $(n=30)$, and $4^{\text {th }}$ Grade students $(n=29)$; and Science-Literature Faculty, Sociology Department $3^{\text {rd }}$ Grade students $(n=36)$. The participants were given forms and were asked to state their demographic data and assess the images shown to them through projector (between 1-5 points). The images were shown for several times together and separately in order to make the participants view them in an accurate manner. The 'SPSS Statistics 22' statistical package program was used in the analyses in the study. The One Way Variance Analysis (ANOVA) was used in comparing the average values.
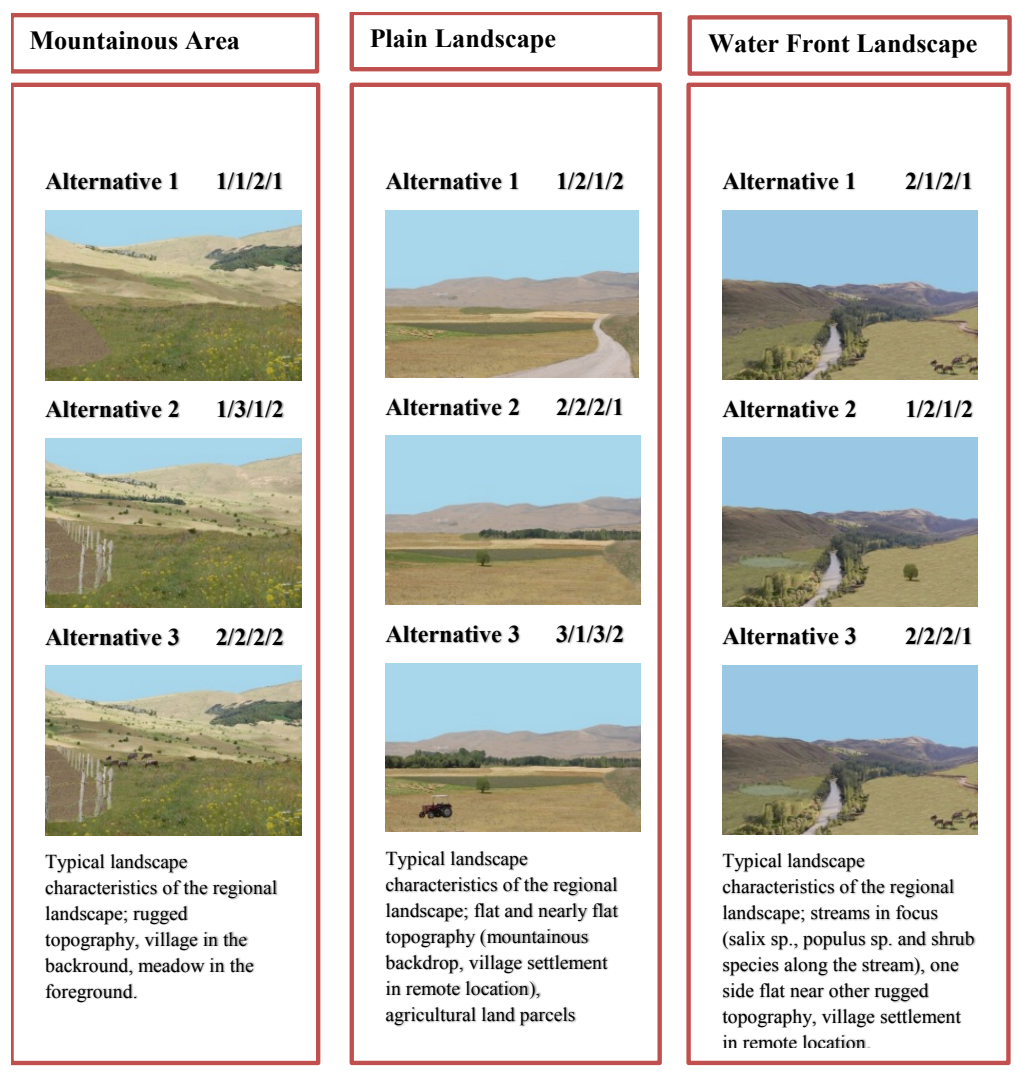

Figure 2. Landscape alternatives presented to participants (encoding, refers to the usage level of the elements.)

Submit Date: 16.07.2019, Acceptance Date: 29.10.2019, DOI NO: 10.7456/11001100/002

Research Article - This article was checked by Turnitin

Copyright (C) The Turkish Online Journal of Design, Art and Communication 


\section{Findings}

$56,8 \%$ of the participants were male, and $49,5 \%$ were born in metropolitan city centers. $2,1 \%$ of them had an income at and over 5001 TL monthly in their families (Table 1).

Table 1. Personal characteristics of the participants

\begin{tabular}{llcc}
\hline $\begin{array}{l}\text { Demographic } \\
\text { characteristics }\end{array}$ & Participants & Total(Frequency) & Total(\%) \\
\hline Gender & Male & 54 & 56,8 \\
\cline { 2 - 4 } & Female & 41 & 43,2 \\
\hline \multirow{2}{*}{ Income } & $850-1500 \mathrm{TL}$ & 34 & 35,8 \\
\cline { 2 - 4 } & $1501-3000 \mathrm{TL}$ & 40 & 42,1 \\
\cline { 2 - 4 } & $3001-5000 \mathrm{TL}$ & 19 & 20,0 \\
\cline { 2 - 4 } & $\geq 5001 \mathrm{TL}$ & 2 & 49,5 \\
\hline Birthplace & Big town center & 47 & 37,9 \\
\cline { 2 - 4 } & Small town center & 36 & 12,6 \\
\cline { 2 - 4 } & Village & 12 & \\
\hline
\end{tabular}

$70,5 \%$ of the participants, who participated in the study, stated that they had rural area experiences, and it was observed that the majority of them $(56,8 \%)$ did not have anything to do with farming (Table 2).

Table 2. The distribution of relationships participants with rural area

\begin{tabular}{lllcc}
\hline & Participants & Total(Frequency) & Total(\%) \\
\hline \multirow{2}{*}{ Rural areas experience } & Yes & 67 & 70,5 \\
\cline { 2 - 4 } & No & 28 & 29,5 \\
\hline \multirow{2}{*}{ Be interested in farming } & Yes & 41 & 43,2 \\
\cline { 2 - 4 } & No & 54 & 56,8 \\
\hline
\end{tabular}

The average points of all scenarios that were prepared are given in Table 3 . When the average points are considered it is observed that the images that received the highest points among the landscape types are D3, S3 and O3; and the image that received the lowest point is D1 (Figure 3).

Table 3. Mean and standard deviation for each image

\begin{tabular}{ccccc}
\hline Scene no & Mean(M) & Std. deviation & Variance & N \\
\hline $\mathrm{D} 1$ & 1,93 & 1,044 & 1,090 & 95 \\
\hline $\mathrm{D} 2$ & 2,84 &, 903 &, 815 & 95 \\
\hline $\mathrm{D} 3 *$ & 4,11 & 1,077 & 1,159 & 95 \\
\hline $\mathrm{O} 1$ & 2,46 & 1,382 & 1,911 & 95 \\
\hline $\mathrm{O} 2$ & 2,79 & 1,030 & 1,062 & 95 \\
\hline $\mathrm{O} 3^{*}$ & 3,68 & 1,084 & 1,176 & 95 \\
\hline $\mathrm{S} 1$ & 3,42 & 1,225 & 1,502 & 95 \\
\hline $\mathrm{S} 2$ & 3,12 & 1,219 & 1,486 & 95 \\
\hline $\mathrm{S} 3^{*}$ & 4,05 &, 961 &, 923 & 95 \\
\hline
\end{tabular}

*highest rated images 


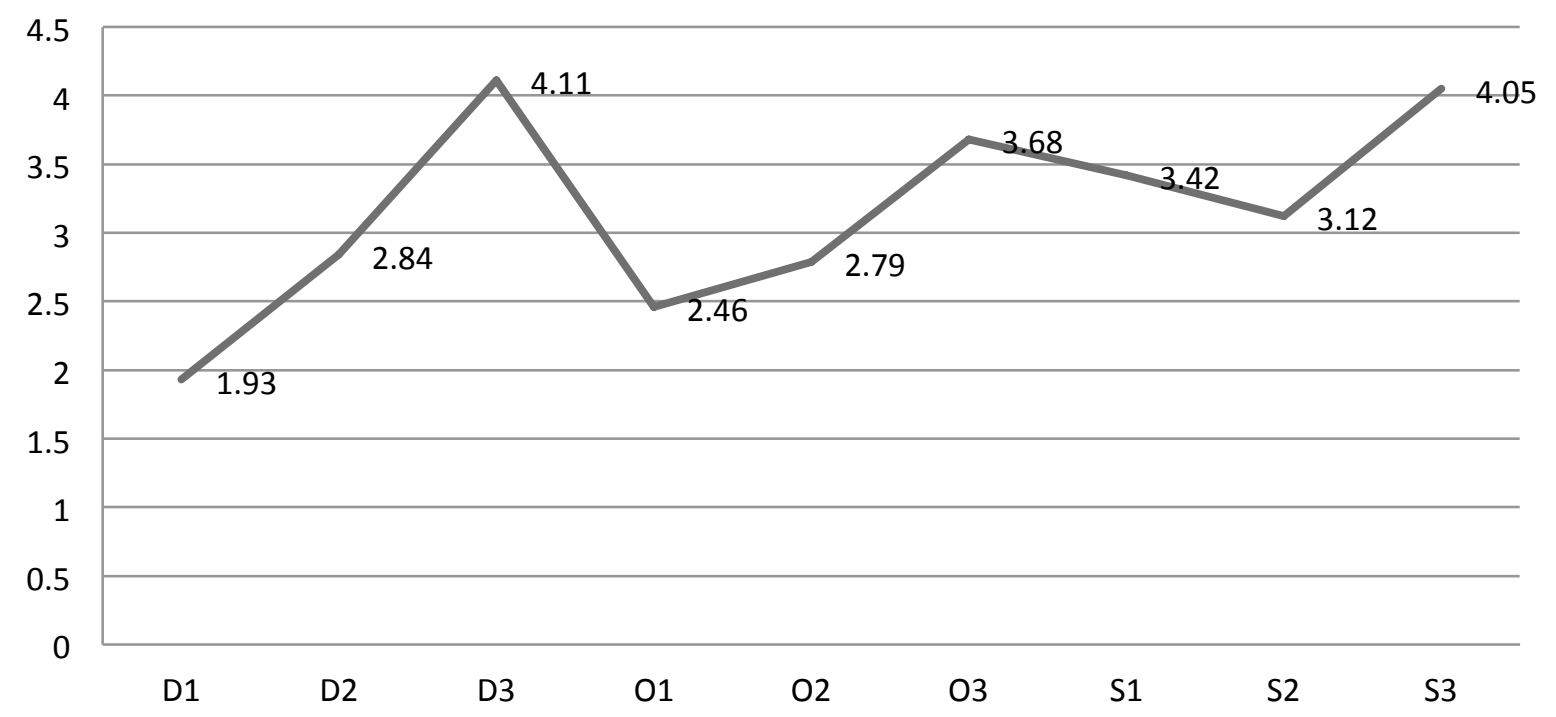

Figure 3. Histogram showing distribution scores received in analysis of the images

As a matter of fact, according to One Way Variance Analysis (ANOVA) results, the difference between the images have been found to be significant $(p<0,001)$ (Table 4$)$.

Table 4. ANOVA test of images as the result of analysis between groups and within groups.

\begin{tabular}{rccccc}
\hline & Sum of Squares & df & Mean Square & F & Sig. \\
\hline Between Groups & 407,557 & 9 & 45,284 & 36,626 & 000 \\
\hline Within Groups & 1044,754 & 845 & 1,236 & & \\
\hline Total & 1452,311 & 854 & & & \\
\hline
\end{tabular}

The codes that were given according to the usage levels of the elements in the scenarios with high points are given in Table 5. In this context, linear, massive and scattered elements are the ones that come to the forefront in Mountainous Landscape, and there is animal existence as well. In the Water Front Landscape, on the other hand, curved and segmental elements come to the forefront, and animal existence preserves its value. In Plain Landscape, the linear, point and scattered elements are the outstanding typologies. 
Table 5. The codes that were given according to the usage levels of the elements (for high points scenario)

\begin{tabular}{lll}
\hline Mountainous Landscape 2222 & $\begin{array}{l}\text { Water Front Landscape } \\
\mathbf{2 2 2 1}\end{array}$ & $\begin{array}{l}\text { Plain Landscape } \\
\mathbf{3 1 3 2}\end{array}$ \\
\hline $\begin{array}{l}\text { Animal Existence } \\
\text { yes }\end{array}$ & $\begin{array}{l}\text { Curved element } \\
\text { road yes }\end{array}$ & $\begin{array}{l}\text { Linear element } \\
\text { vegetation wholly yes }\end{array}$ \\
\hline $\begin{array}{l}\text { Linear element } \\
\text { fence yes }\end{array}$ & $\begin{array}{l}\text { Segmental element } \\
\text { agricultural area yes }\end{array}$ & $\begin{array}{l}\text { Curved element } \\
\text { road no }\end{array}$ \\
\hline $\begin{array}{l}\text { Massive element } \\
\text { vegetation yes }\end{array}$ & Animal Existence & $\begin{array}{l}\text { Point element } \\
\text { two elements }\end{array}$ \\
\hline $\begin{array}{l}\text { Scattered element } \\
\text { vegetation yes }\end{array}$ & yes & $\begin{array}{l}\text { Scattered element } \\
\text { bundle in agricultural area yes }\end{array}$ \\
\hline
\end{tabular}
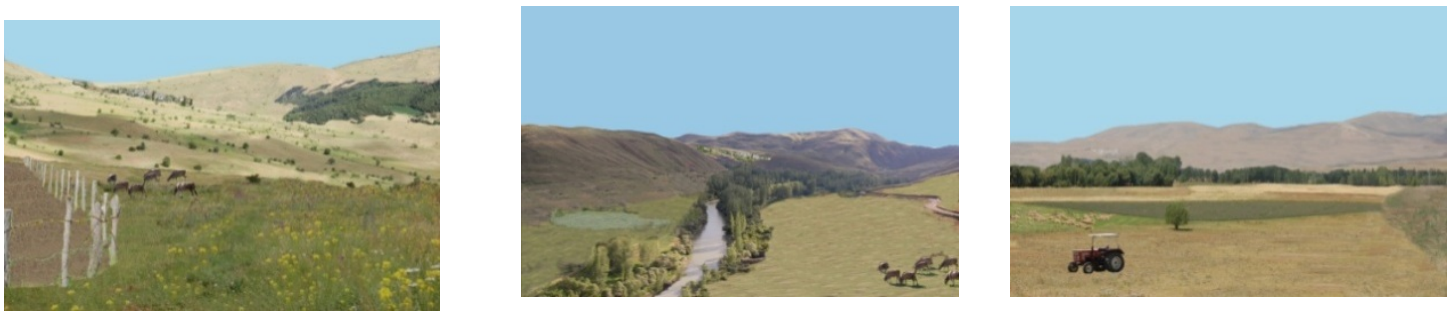

\section{CONCLUSION}

Landscapes include elements whose numbers increase based on their size. It must not be underestimated that detailed studies must be conducted for wider landscape areas. In the present study, the typological assessment of the landscape of Upper Coruh Valley, which is a special landscape character area of Turkey, has been performed. Çoruh Valley is located within the borders of the Eastern Black Sea region of the Black Sea Region. Bayburt and Artvin city center, Pazaryolu, İspir, Yusufeli and Borçka district centers and many village settlements are located in the valley. At the base of the expanding valley around Bayburt, settlements have the opportunity to develop a wider area. Due to the increasing importance of the east and north-increasing height and slope of the progression through the Coruh, settlements are aligned in a narrower area in the bottom of the valley and slopes.

The mountainous and rugged topography has caused the settlements to show a scattered form. In the region where cereal production takes place in the first place (feed plants, tuberous plants, industrial plants and legumes, respectively), the economy is based on agriculture and animal husbandry. In some parts, undergrowth training and vegetable-fruit farming are also carried out. In this region where the industry is not developing, the support of agricultural landscape elements and rural character is a priority strategy in the region. In the light of all these results and observations, the prominent suggestions are listed below: Most of the participants not only urban users are individuals with experience in rural areas. However, since the participants did not have experience of local farming, their evaluations were merely the visual impact and scenic beauty of the landscape values. This situation is ideal for the identification of tourism and recreation-based visitor expectations. Undoubtedly, studies on the approach of farmers and breeders may point to different conclusions.

The Mountainous Typology, which came to the forefront in this study, also includes the massive and scattered vegetation as well as linear elements. In addition to these, animal existence is also present. The Mountainous Landscape show the landscape character in which animal breeding is a part of the landscape. In Mountainous Landscapes, massive and scattered vegetation must be preserved in existing areas, new areas must be opened, and the natural character of the area must be emphasized.

Submit Date: 16.07.2019, Acceptance Date: 29.10.2019, DOI NO: 10.7456/11001100/002

Research Article - This article was checked by Turnitin

Copyright $\mathbb{C}$ The Turkish Online Journal of Design, Art and Communication 
Water Front Landscape has shown a different typology in this study. While there are agricultural areas in the quality of road and segmental element as curved element, the animal existence preserved its place. In this landscape type, the point elements lost their importance. The natural form of vegetation in water and in waterfront showed integrity in curved elements, and segmental elements were a coherent factor in this harmony. In the waterfront, on the other hand, naturally-curved roads made with natural materials that are suitable to the natural structure of the area and agricultural product areas will be the works that support the authentic character of the landscapes.

In Plain Landscape; the linear, point and scattered elements were the outstanding typologies. Along the plain, the linear vegetation that follow the horizon line, the solitary tree and agricultural machinery, the point elements and the bundles located in the agricultural area seem to be the parts that complete the whole landscape in an accurate manner. Plain Landscape must be emphasized with clear lines. The character of the plain must be strengthened with trees that surround the landscape with linear design, solitary plants, agricultural machinery and production works.

While the rural development policies are set forth at country level, the national and environmental priorities must be defined at regional level. Each landscape must be assessed with its own internal dynamics and natural-cultural properties. A landscape planning that will be performed with the experiences and preferences of the farmers, who are the users of the rural areas, and of the visitors, who are the secondary actors in the process, may have a sustainable quality. The rural and cultural tissue, which is becoming extinct with each passing day with industrial and energy production interventions, may only be preserved with this way.

\section{REFERENCES}

Anonymous, 2000. European Landscape Convention. Explanatory Report, 20.10.2000, Florence.

Anonymous, 2011. The Eu Biodiversity Strategy to 2020. Publications Office of the European Union.

Anonymous, 2013a. World Population Prospects: the 2012 Revision, http://www.un.org/en/development/desa/news/population/un-report-world-population-projected-toreach-9-6-billion-by-2050.html, access date: 15.06.2016

Anonymous, 2013b.Yukarl Havza Sel Kontrolü Eylem Planı 2013-2017. T.C. Orman ve Su İşleri Bakanlığı, Ankara.

Anonymous, 2014. Agriculture Development, Food Security and Nutrition. UNGA. A/69/279,http://www.un.org/ga/search/view_doc.asp?symbol=A\%20/69/279\&Lang=E. access date: 15.06.2016.

Arnberger, A., Eder, R., 2011. Exploring the Heterogeneity of Rural Landscape Preferences: An Image-Based Latent Class Approach. Landscape Research, Vol. 36, No. 1, 19-40, DOI: 10.1080/01426397.2010.536204.

Arriaza, M., Canas-Ortega, J.F., Canas-Madueno, J,A., Ruiz-Aviles, P., 2004. Assessing the Visual Quality of Rural Landscapes. Lanscape and Urban Planning, 69, 115-125. DOI: 10.1016/j.landurbplan.2003.10.029

Brown, T., Daniel T.C.,1987. Context Effects in Perceived Environmental Quality Assessment: Scene Selection And Landscape Ratity Journal of Environmental Psychology, 7(3), 233-250.

Cloquell-Ballester, V.A., Torres-Sibille, A.C., Cloquell-Ballester, V.A., Santamarina-Siurana, M.C., 2012. Human alteration of the rural landscape: Variations in visual perception. Environmental Impact Assessment Review 32, 50-60.

Fuante de Val, G., Atauri A.J., Lucio J.V., 2006. Relationship Between Landscape Visual Attributes and Spatial Pattern İndices: A Test Study in Mediterranean- Climate Landscapes. Landscape and Planning, 77 (4), 393-407.DOI: 10.1016/j.landurbplan.2005.05.003

Gruehn, D., Roth, M., 2008. New Approaches in Visual Landscape Assessment and Modelling. International Landscape Architecture Conference Proceedings, Jelgava, Latvia. 
Hull, R. B. IV, Revell G.R. B.,1989. Cross-Cultural Comparison of Landscape Scenic Beauty Evaluations: A Case Study in Bali. Journal of Environmental Psychology, 9(3), 177-191.

Kaplan, R., Talbot J.F., 1988. Ethnicity and Preference for Natural Settings: A Review and Recent Findings. Landscape and Urban Planning, 15(1-2), 107-117.

Lokocz, E., Ryan, R.L., Sadler, A.J., 2011. Motivations for Land Protection and Stewardship: Exploring Place Attachment and Rural Landscape Character in Massachusetts. Landscape and Urban Planning 99, 65-76.

Özey, R.,1988. Bayburt ve Çevresinin Cografi Özelliklerine Genel Bir Bakış. Türk Tarihinde ve Kültüründe Bayburt Sempozyumu (23-25 Mayıs 1988), Ankara, s.437.

Paquette, S., Damon, G., 2003. Changing Ruralities, Changing Landscapes: Exploring Social Recomposition Using A Multi-Scale Approach. Journal of Rural Studies, 19, 425-444. DOI: 10.1016/S0743-0167(03)00006-8

Rogge, E., Nevens F., Gulinck, H., 2007. Perception of Rural Landscapes in Flanders: Looking Beyond Aesthetics. Landscape and Urban Planning, 82, 159-174. DOI: 10.1016/j.landurbplan.2007.02.006

Sato, C.F., Wood, J.T., Stein, J.A., Crane, M., Okada, S., Michael, D.R., Kay, G.M., Florance, D., Seddon, J., Gibbons, P., Lindenmayer, D. B., 2013. Natural Tree Regeneration in Agricultural Landscapes: The Implications of Intensification. Agriculture, Ecosystems and Environment, 230, 98104.

Soy-Massoni E., Langemeyer J., Varga D., Sáez M., Pintó J., 2016. The Importance of Ecosystem Services in Coastal Agricultural Landscapes: Case Study from the Costa Brava, Catalonia. Ecosystem Services, 17, 43-52.

Türk, Y.A., 2006. A Method For Integrated Urban Planning and Design. KTU Science Institute, , $\mathrm{PhD}$ Thesis.

Van der Zanden, E.H., Levers, C., Verburg, P.H., Kuemmerle, T., 2016. Representing Composition, Spatial Structure and Managementintensity of European Agricultural Landscapes: A New Typology. Landscape and Urban Planning, 150, 36-49.

Van Zanten B.T., Zasada I., Koetse M.J., Ungaro F., Häfner K., Verburg P.H., 2016. A Comparative Approach to Assess the Contribution of Landscape Features to Aesthetic and Recreational Values in Agricultural Landscapes. Ecosystem Services, 17, 87-98.

Vecchiato, D., Tempesta T., 2013. Valuing the Benefits of an Afforestation Project in A Peri-Urban Area with Choice Experiments. Forest Policy and Economics, 26, 111-120, DOI: 10.1016/j.forpol.2012.10.001

Westerberg V. H., Lifran R., Olsen S.B., 2010. To Restore or Not? A Valuation of Social and Ecological Functions of the Marais des Baux Wetland in Southern France. Ecological Economics, 69, 2383-2393. 